\title{
Potential use of green banana biomass in the preparation of chocolate cake and salty pie
}

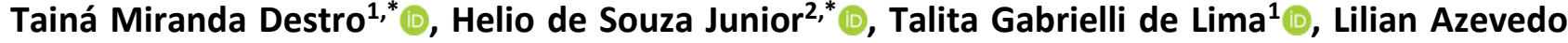 \\ Miranda $^{3}$ and Marcia Pires Ferreira ${ }^{1}(0)$
}

${ }^{1}$ Centro Universitário Filadélfia, (Unifil), Departamento de Agronomia. Avenida Juscelino Kubitschek, 1626, CEP 86020000, Londrina, PR, Brazil. ²Universidade Norte do Paraná (UNOPAR), Setor de Agronomia, Avenida Paris, 675, Jardim Piza, CEP 86041-140, Londrina, PR, Brazil. '3 Universidade Estadual de Londrina (UEL), Centro de Ciências Agrárias (CCATAM) - Rodovia Celso Garcia Cid, Km 380, s/n -Campus Universitário, CEP 86057-970, Londrina, PR, Brazil. *Cocorresponding authors, E-mails: 1987taina@gmail.com / helioszjr@gmail.com

\begin{abstract}
The green banana biomass is a new product which has easy applicability in recipes, adding benefits to people's health because it is an ingredient high in resistant starch, recommended for prevention and support in the treatment of diseases such as diabetes, obesity, dyslipidemia, cancer, intestinal disorders, celiac disease etc. The aim of this study was to investigate the potential use of green banana biomass in the preparation of chocolate cake and salty pie. The biomass replaced part of the wheat flour used in the recipes at a ratio of $30 \%$ and $50 \%$ for the cake and pie, respectively. The green banana biomass, with and without skin, were analyzed for proximate composition. Tests were conducted ranking preference for the cakes and salty pies. The recipe for chocolate cake containing biomass with the peel was the most preferred $(60 \%)$, and the traditional recipe was the least preferred (54\%). In reference to the salty pies, among the most preferred samples, those containing biomass from the pulp of unripe banana came in first place (44\%) and, among the least favorite, the traditional recipe prevailed (54\%). In an analysis of purchase intention all the preparations had a good intention of purchase. Using the biomass of green bananas for the purpose of using it's prebiotic property promotes the intake of a functional agent in food in a simple manner, giving rise to a new product.
\end{abstract}

Keywords: Prebiotic, resistant starch, human nutrition, functional foods, food technology, antioxidant substances.

\section{INTRODUCTION}

The banana (Musa spp.) is one of the most consumed fruit in the world, being cultivated in most tropical countries. Its production is concentrated in most tropical countries, and its culture is considered, worldwide, the fourth most important food crop, second only to rice, corn and wheat (Nascimento, Pierre, Santo, Felice, \& Rizzo, 2020). Bananas have also contributed to reducing food insecurity in producer country populations (Aurore, Parfaitb, \& Fahrasmane, 2009; Food and Agriculture Organization of the United Nations [FAO], 2015).

Brazil is fifth largest producer of the fruit, behind Ecuador, China, the Philippine Islands and India, generating more than 500 thousand direct jobs, with production close to 7 million tons in 2012, in an area of approximately 481 thousand ha (FAO, 2015). However, fruit export represents only a small portion of this production, followed by a high index of crop and post crop losses - over $50 \%$ - due to inadequate management (Taipina et al., 2002).

Unlike the ripe fruit, the green banana is rich in complex carbohydrates, including the resistant starch, being low in sugar and having an astringent flavor, caused mainly by the presence of tannin. It is also more resistant, which leads to less loss. The use of the green banana in byproducts would therefore represent an excellent way to increase production performance (Silva \& Araújo, 2009). It is also possible to use the byproducts present in the banana production chain such as the male inflorescence the flowers, the straw, banana plant fibers, leaves, the aerial part as salt substitute after being transformed in ashes, the inner part of the pseudo-stem, etc. (Kinupp \& Lorenzi, 2014).

In order to be used, the green banana is transformed into biomass, through cooking and posterior homogenization, or into flour. These processes alter the sensorial, chemical and physical characteristics of the plant, resulting in a product with neutral flavor and aroma (Silva \& Araújo, 2009; Valle \& Camargos, 
In general, mineral salts are present in greater amounts in the green fruit such as potassium, phosphate, calcium, sodium and magnesium, in addition to iron, manganese, iodine, aluminum and zinc. The main vitamins present in the fruit are vitamin C and complex B (B1, B2 and niacin) (Ramos, Leonel, \& Leonel, 2009). Key proteins are albumin and globulin, however, in small amounts. In relation to the amino acids, there is the predominance of the asparagine, glutamine and histidine (Bianchi, 2010).

The chemical composition of the banana goes under some modifications during ripening. Among them, there is the conversion of great part of the starch into sugars, with the predominance of sucrose over fructose and glucose (Taipina et al., 2002). The chemical composition of the banana pulp and peel can be seen in Table 1 and the mineral com position of the banana pulp and peel can be seen in Table 2 (Medeiros, Azevedo, Gondim, Gurgel, \& Dantas, 2005).

Table 1. Approximate Chemical Composition of the green banana peel and pulp, in 100g.

\begin{tabular}{l|l|l|l|l|l|l|l}
\hline & $\begin{array}{c}\text { Humidity } \\
(\mathbf{g})\end{array}$ & $\begin{array}{c}\text { Carbohydrates } \\
\mathbf{( g )}\end{array}$ & $\begin{array}{c}\text { Proteins } \\
\mathbf{( g )}\end{array}$ & $\begin{array}{c}\text { Fibers } \\
\mathbf{( g )}\end{array}$ & $\begin{array}{c}\text { Ashes } \\
(\mathbf{g})\end{array}$ & $\begin{array}{c}\text { Lipids } \\
(\mathbf{g})\end{array}$ & $\begin{array}{c}\text { Energy } \\
(\mathbf{k c a l})\end{array}$ \\
\hline Pulp & 69.89 & 26.30 & 1.95 & 1.08 & 0.70 & 0.07 & 113.66 \\
\hline Peel & 88.75 & 6.95 & 1.03 & 1.64 & 0.97 & 0.66 & 37.86 \\
\hline
\end{tabular}

Source: Medeiros et al. (2005).

Table 2. Approximate mineral composition of the green banana, in 100g.

\begin{tabular}{l|l|l|l|l|l|l|l}
\hline & K (mg) & Na $(\mathrm{mg})$ & Ca $(\mathrm{mg})$ & $\mathrm{Mg}(\mathrm{mg})$ & $\mathrm{Al}(\mathrm{mg})$ & Fe $(\mathrm{mg})$ & Zn (mg) \\
\hline Pulp & 219.66 & 61.78 & 39.58 & 48.57 & 6.39 & 1.18 & 0.53 \\
\hline Peel & 335.06 & 41.86 & 66.17 & 22.63 & 7.40 & 1.17 & 0.84 \\
\hline
\end{tabular}

Source: Medeiros et al. (2005).

The banana is a source of substances with antioxidant function, including phenols and flavonoids such as catechins, epicatechins, gallo-catechins, dopamine and tannin, mainly when green and in the peel. This may represent around 30\% of its weight (Aurore et al., 2009; Gouveia \& Zandonadi, 2013).

In addition to their basic nutritional functions, functional foods or ingredients produce metabolic and/or physiological effects, when consumed as part of our usual diet, which are beneficial to our health, being safe for consumption without medical supervision. In Brazil, some studies show that most people do not know the meaning of the term "functional food" (Silva, Santos, Nascimento, \& Pimentel, 2010).

Omega 3 fatty acids, vegetal fibers, soybean protein, vegetal sterols and stanols, probiotics and prebiotics can be mentioned among the active composites found in functional foods (Favero $\mathrm{w} / \mathrm{d}$ ).

Prebiotics are non-edible food components which are beneficial to the host since they stimulate, selectively, the proliferation or activity of desirable bacterial populations in the colon. Additionally, they can inhibit pathogens multiplication, guaranteeing additional benefits to the host health. These components act most frequently in the large intestine (Saad, 2006).

The most important characteristic of the banana as a prebiotic food is its high resistant starch content (Silva, 2003) which is fermented in the large intestine, mainly by bifidobacteria (Pereira, 2007). Resistant starch ingestion among Brazilians has decreased throughout the years. However, the consumption of the so-called prebiotics has increased. The use of the green banana biomass for its prebiotic property promotes the intake of a functional agent in food in a simple way, giving rise to a new product (Ramos et al., 2009; Saad, 2006).

Resistent starch can be divided according to the speed at which food is digested in vitro into: rapidly digestible, slowly digestible, and resistant starch, which resists to the action of the digestive enzymes (Ramos et al., 2009). The resistant starch can be classified, according to its physical-chemical structure and 
susceptibility to the enzymatic hydrolysis, as type 1, 2, 3, 4 and 5 .

The resistant starch 1 is physically inaccessible in the food cell matrix mainly due to the proteins and cell walls. Whole or partially grounded cereal, legumes or other seeds belong to this group. Type 2 is the resistent starch which in its native state is found in non-cooked foods such as green bananas and raw potatoes. Type 3 is formed when the resistent starch goes under retrogradation, present in fresh and cooked potatoes, breakfast cereals and bread. Type 4 is chemically modified and resistant to enzymes due to the formation of interactions among its components, different from those found in the digestible starch, by heat treatment or due to the presence of some substitutes (Lobo \& Silva, 2001). Type 5 resistant starch is formed by a physical interaction between debranched helical starch amylose and a long chain fatty acid, such as palmitic or stearic acid. Resistant starch types may coexist in the same food as in green bananas where Type 1 and 2 are found (Anderson et al., 2014).

In physiological terms, resistant starch is defined as "the sum of the starch and the products derived from its degradation, which are not digested and absorbed by the small intestine of healthy individuals". Thus, this fraction of the starch shows a behavior similar to that of the food fiber, being more similar to that of insoluble fibers (Silva \& Araújo, 2009).

Ramos et al. (2009) evaluated flour made with green bananas from several genotypes and concluded that all of them presented considerable resistant starch content with values that varied, on average, from $10 \%$ to $40 \%$. The Nanicão (Super Dwarf) type showed greater quantity of resistant starch.

Starch granules from Musa AAA-Nanicão and Musa AAB-Terra can be observed in Figure $1 \mathrm{~A}$ and B, respectively, and the same post-hydrolysis by swine pancreatic a amylase, showing reduced starch granules, in Figure $1 \mathrm{C}$ and $\mathrm{D}$, respectively. Smooth, oval, elongated and differentiated forms predominated among granules from the two banana cultivars (Freitas \& Tavares, 2005).

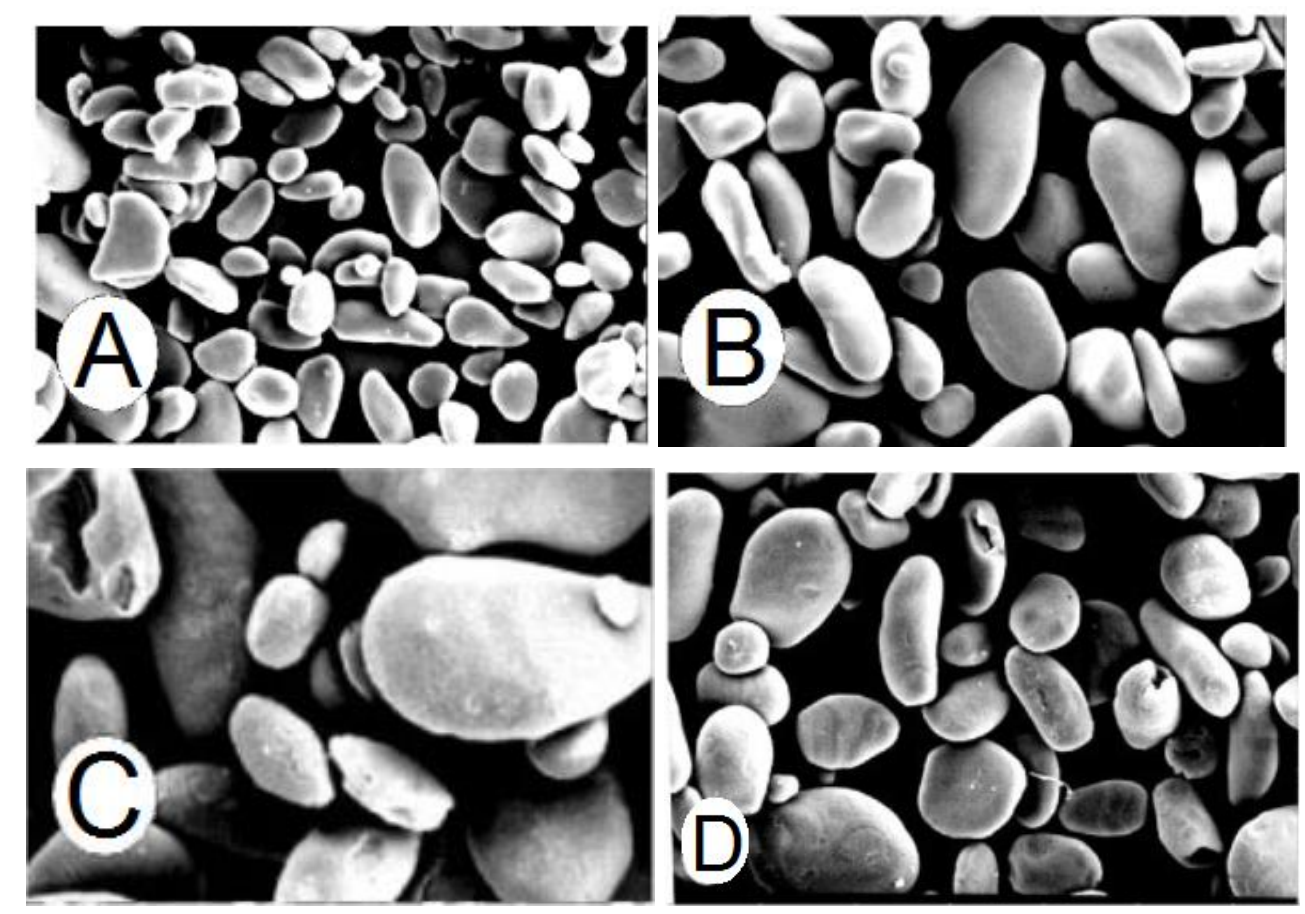

Figure 1. MEV Micrograph of the green banana native starch: A: Musa AAA-Nanicão (330x); B: Musa AABTerra (430x) and starch treated with in vitro $\alpha$-amylase: C: Musa AAA-Nanicão (1000x); D: Musa AAB-Terra (1000x) (Freitas \& Tavares, 2005).

During digestion, the slow fermentation of the resistant starch prevents the common discomfort caused by the production of gases. It promotes an increase in faecal bolus, improvement in feces consistency and less occurrence of abdominal pain and the sensation of incomplete bowel movement, which is important to prevent pathologies such as constipation, diverticulitis and hemorrhoids and to dilute toxic components (Pereira, 2007). It also accelerates the recovery of diarrhea, both acute and chronic (Rabbani, Larson, Islam, Saha, \& Kabir, 2010) and can help decrease the serum levels of cholesterol and triglycerides, contributing to the treatment of dyslipidemia and preventing heart diseases (Bianchi, 2010). The presence of fermenting substrates and flavonoids helps to prevent inflammatory diseases of the intestine and to maintain the mucous metabolic needs (Pereira, 2007). 
During resistant starch fermentation there is the production of short chain fatty acids (SCFA), mainly the butyrate which inhibits the growth of cancer cells caused by the pH reduction in the large intestine and the propionate, a mediator of hepatoglucose production and lipid metabolism.

The SCFA also contributes to the production of progressive diffuse energy - an energy liberated during slow digestion - helping to keep individuals with the sensation of fullness for a longer period of time, being also used to treat obesity. The SCFA promotes a small glycemic response and, consequently, a more adequate insulin reaction, presenting low glycemic index, increasing glucose tolerance in the posterior meal, preventing an overload of $\beta$ pancreatic cells. The SCFA contributes with the daily energy needs of the host and stimulates the colonic blood flow, using fluids and electrolytes. Therefore, it helps to treat diabetes, mainly of Type 2 (Pereira, 2007).

Celiacs, individuals who cannot ingest any food that contains gluten, have great difficulty eating, since this substance is present in several grains such as wheat, barley and oatmeal. By the physical-chemical characteristics of the resistant starch, in special that found in the green banana, the biomass is considered useful for the preparation of several recipes as replacements for the grains mentioned above (Bianchi 2010). People with other disorders connected to the gluten can also benefit such as those with herpetiform dermatitis and gluten sensitivity (Gouveia \& Zandonadi, 2013).

The biomass can be stored in the fridge for three days or in the freezer for three months (Valle \& Camargos, 2010). It can be widely used in home or industrial cooking, including collective meals, bread making and confection, juices, meat and sausages, ice cream, sweet and salty food preparations, without affecting their taste and improving their nutritional value due to its low caloric, lipids and sugar contents and higher AR and fiber contents. It can also be used as thickeners, substituting the traditional wheat, soybean, manioc starch and corn starch and reducing or eliminating the use of milk and hydrogenated vegetal oil (Bianchi 2010). It acts as colon stabilizer, gelling agent (Gouveia \& Zandonadi, 2013) and edible film (Saifullah, Abbas, Yeoh, \& Azhar, 2009). It provides better appearance, texture, mouthfeel, expansion and crispiness (Pereira, 2007).

Other examples of green banana application in food are shakes, yogurts, jams, pies, oatmeal, coffee, stuffing, vitamins, soups, etc. (Bianchi 2010). The green banana was tested with good results in works with preparations such as pasta, mayonnaise, cookies, corn cream, among others (Gouveia \& Zandonadi, 2013; Daramola \& Osanyinlusi 2006).

The use of green banana biomass has, therefore, great economic appeal, incrementing the exploration of the fruit in a rational and modern way, strengthening the development of the sectors connected to the banana culture in several Brazilian regions and around the world. It also has strong social appeal as an ally in the fight against malnutrition which, if widely disseminated, can contribute to the eradication of hunger and mortality in underprivileged communities, reaching all age groups (Valle \& Camargos, 2010).

Consumers options need to be diversified and new commercial niches need to be developed, to enable better use of production. Product identification and labeling signs have been set up to ensure product quality and origin, create added value, and enable consumers to distinguish products with particular and specific qualities (Aurore et al., 2009), such as organic and/or locally grown.

Taking into account the high food insecurity rates and unhealthy eating habits of many people, it is important to increase the number of studies and the dissemination of such foods, especially on the green banana biomass for being an economically accessible product, easy to prepare and with raw material widely available all year long.

The object of this study was to investigate the use potential of the green banana biomass in the preparation of chocolate cakes and salty pies. The development of this study was approved by the Unifil Ethical Committee for Research on Human Beings, being conducted according to the technical norms of Biosafety and Ethics.

\section{MATERIALS AND METHODS}

\section{Green Banana Biomass}

The green banana pulp, known as biomass, is characterized by high starch content, low levels of humidity, sugars and aromatic compounds. It can be used to enrich various products, such as breads, pasta in general, ice cream and food containing starch in its composition, since it does not alter the flavor or smell of the food and contributes to increasing the volume of the food, in addition to incorporating vitamins, minerals and fibers. 
There are three types of biomass processing: biomass $\mathrm{P}$ (pulp); biomass $\mathrm{F}$ (using the green peel) and the whole biomass in which the peel and pulp are used (Nascimento et al., 2020). Green bananas were used for the elaboration of banana biomass, as it is an economically accessible product, easy to prepare and with the raw material widely available throughout the year.

\section{Green Banana Pulp and Peel Biomass Production and Recipes Development}

In this study, the banana cultivar Nanica, from the subgroup Cavendish (Musa acuminata), was used. In order to prepare the green banana pulp and peel biomass, the bananas were first washed and next placed with their peels in a pressure cooker filled with boiling water and cooked for eight minutes after pressure started. Fire was turned off and the bananas continued cooking in the cooker until pressure was reduced naturally for 10 minutes. The bananas were removed from the cooker and the peel pulps were separated to prevent them from turning into flour, and the pulps were processed immediately in the blender.

After having discarded the black tips of the peels, they were placed in a solution with one liter of water containing $50 \mathrm{~mL}$ of lemon juice and left marinating for 40 minutes. Later they were rinsed and processed in the blender.

\section{Development of revenues}

The recipes used can be found in Figure 2. A traditional recipe was used to prepare the chocolate cake. Based on this traditional recipe, two experimental recipes were developed, by substituting $30 \%$ of wheat flour. In one of these recipes, one of the cups of wheat flour was substituted by one cup of banana pulp biomass and, in the other recipe, one of the cups of wheat flour was substituted by $1 / 2$ a cup of pulp biomass and $1 / 2$ a cup of green banana peel biomass.

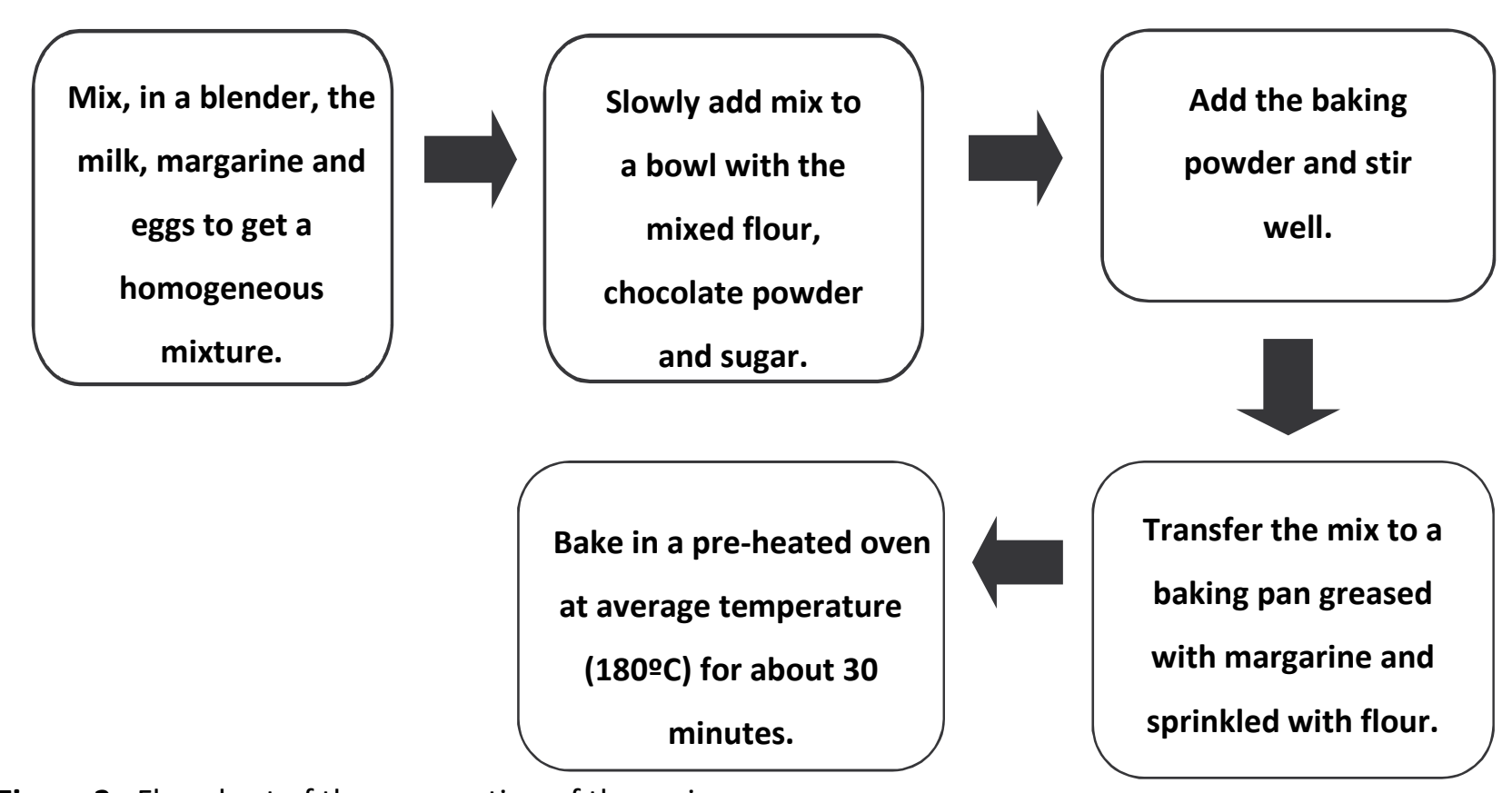

Figure 2. Flowchart of the preparation of the recipe

Source: Elaborated by the authors.

The recipe for chicken pie was developed from a standard recipe. Based on this standard recipe, two recipes were developed by substituting $50 \%$ of the wheat flour. In one of the recipes, one of the cups of wheat flour was substituted by one cup of green banana pulp biomass and in the other recipe, one of the cups of wheat flour was substituted by $1 / 2$ a cup of pulp biomass and $1 / 2$ a cup of whole green banana biomass.

\section{Sensorial Analysis}

The sensorial analysis was carried out in two distinct days, one to evaluate the chocolate cake and the other to evaluate the salty pie (Figure 3). Each sensorial analysis counted with the participation of 50 non- 
trained judges (total: 100), from both sexes, adults, over eighteen years old, being students and collaborators of Unifil, in Londrina, Paraná. The judges read and signed the Free and Informed Consent Form to participate in the research and received all the information on the tests which were realized at Unifil's Dietetics Techniques Laboratory in Londrina, Paraná.

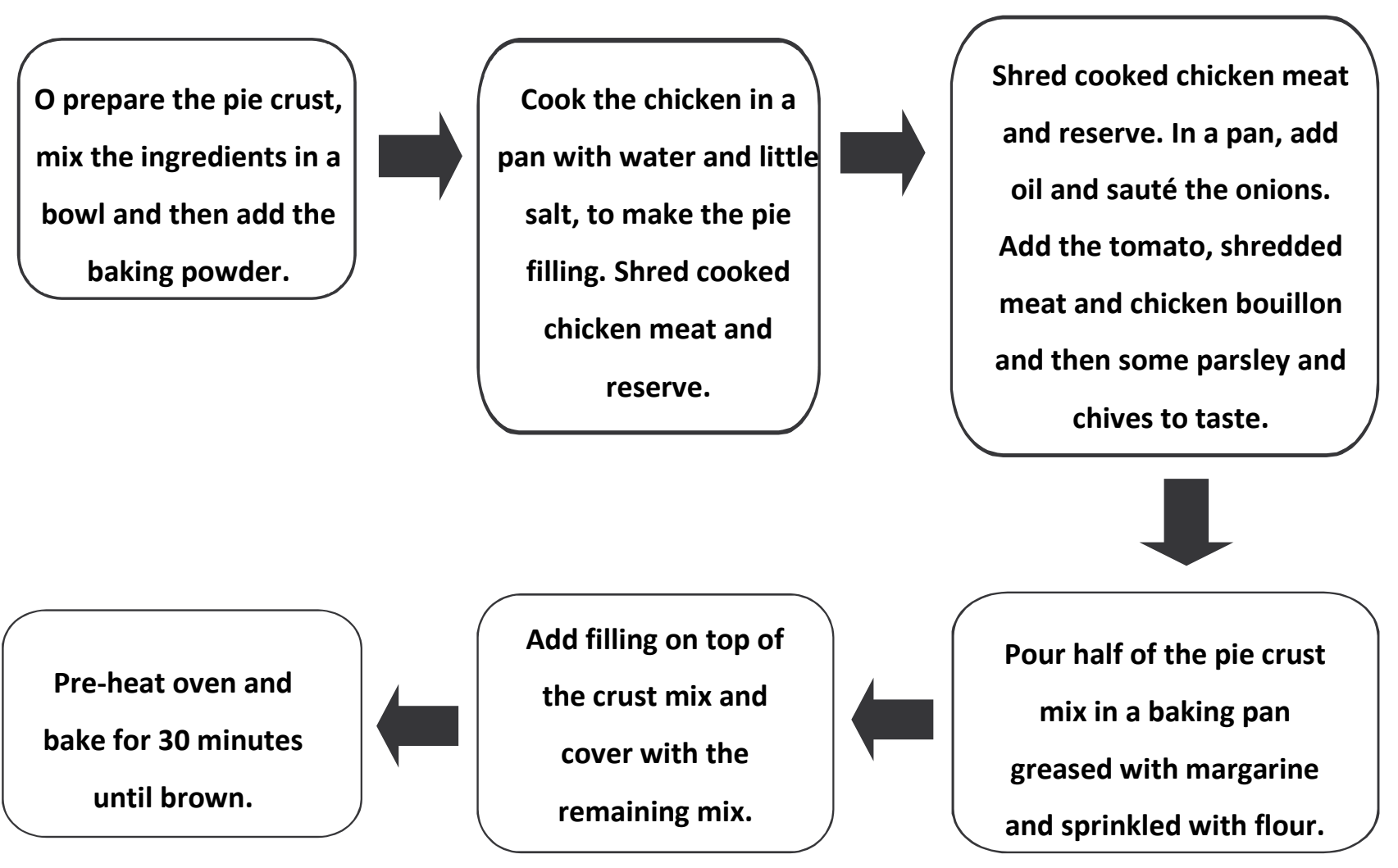

Figure 3. Flowchart of the preparation of the recipe Source: Elaborated by the authors.

For the Preference Ordering Test (Rodas \& Torres, 2009), judges were simultaneously introduced to three samples (one from each recipe), randomly displayed and coded with three digit. They were asked to order the samples according to preference intensity, i.e., in an ascending order of intensity with the less preferred being placed to the left, the intermediary preference in the center and the most preferred to the right.

Cake and pie purchase intention samples were also analyzed by using a five-point scale, using the same card pertinent to each analysis (Rodas \& Torres, 2009). At the bottom of this card, there was an area to register comments, if necessary.

\section{Bromatology Analysis}

Bromatology analyses were realized at Unifil's Bromatology Laboratory and Food Technology Laboratory at Londrina State University. Green banana pulp and peel biomass samples were analyzed for their centesimal composition by determining lipids, protein, humidity and ash contents according to the Instituto Adolfo Lutz (IAL) (2005). The correction factor adopted to determine proteins was 6.25. Analyzes were carried out with three to five replications and total carbohydrates was determined by difference. Results were presented based on 100g of sample humid weight and on a dry basis.

\section{RESULTS AND DISCUSSION}

\section{Analysis of the Centesimal Composition of peel Biomass}

The humidity found in the peel biomass was greater than that found in the pulp. As for the protein, ashes and carbohydrates contents, they were higher in the pulp but the ethereal extract was of the same value (Table 3). The analysis conducted by the Laboratório Bromatológico Nacional (2002) shows less humidity 
(64.79 $\mathrm{g}$ for the pulp and $77.00 \mathrm{~g}$ for the peel), greater amount of ashes $(6.01 \mathrm{~g}$ for the pulp and $0.70 \mathrm{~g}$ for the peel), carbohydrate ( $26.30 \mathrm{~g}$ for the pulp and $6.30 \mathrm{~g}$ for the peel), protein ( $1.33 \mathrm{~g}$ for the pulp and 10.80 $\mathrm{g}$ for the peel), and of lipids ( $5.36 \mathrm{~g}$ for the pulp and $1.32 \mathrm{~g}$ for the peel). These differences may have occurred due to the difference in biomass processing method and raw material used.

\section{Green Banana Pulp}

Green banana pulp biomass results on a dry basis expressed in Table 4 are similar to those found by Borges, Pereira and Lucena (2009) in relation to the centesimal composition (gross protein: $4.50 \mathrm{~g}$, ashes: $2.59 \mathrm{~g}$, ethereal extract: $0.68 \mathrm{~g}$ and glicidic fraction: $87.92 \mathrm{~g}$ ),expressed on a dry basis, in $100 \mathrm{~g}$ of green banana pulp flour.

Table 3. Chemical composition of biomass of green banana pulp and peel in wet basis $(\mathrm{g} / 100 \mathrm{~g})$.

\begin{tabular}{c|c|c|c|c|c}
\hline & $\begin{array}{c}\text { Humidity } \\
\text { (\%) }\end{array}$ & $\begin{array}{c}\text { Gross Protein } \\
\text { (\%) }\end{array}$ & Ashes (\%) & $\begin{array}{c}\text { Ethereal } \\
\text { extract (\%) }\end{array}$ & $\begin{array}{c}\text { Glycidic fraction } \\
\text { (\%) }\end{array}$ \\
\hline Pulp & $79.39 \pm$ & $1.05 \pm 0.00$ & $0.58 \pm 0,03$ & $0.16 \pm 0.02$ & 18.82 \\
& 0.51 & & & & \\
\hline & $95.04 \pm$ & & $0.48 \pm$ & & 3.82 \\
\hline
\end{tabular}

Table 4. Chemical Composition of the green banana pulp and peel biomass in dry basis.

\begin{tabular}{l|c|c|c|c}
\hline & Proteins (\%) & Ashes (\%) & Lipids (\%) & Carbohydrates (\%) \\
\hline Pulp & 5.09 & 2.80 & 0.79 & 91.32 \\
\hline Peel & 9.95 & 9.76 & 3.20 & 77.09 \\
\hline
\end{tabular}

\section{Chocolate Cake Sensorial Analysis}

Most testers (52\%), between 18 and 24 years old, 72\% female and most of them (72\%) Unifil students with a high school degree (78\%) claimed having the habit of consuming food with the intention of preventing diseases. Data from the preference test are shown in Figure 4. The traditional recipe showed statistical difference in relation to the recipe with the pulp and with pulp and peel; however, the two last ones presented no significant difference between them, as shown in Table 4.

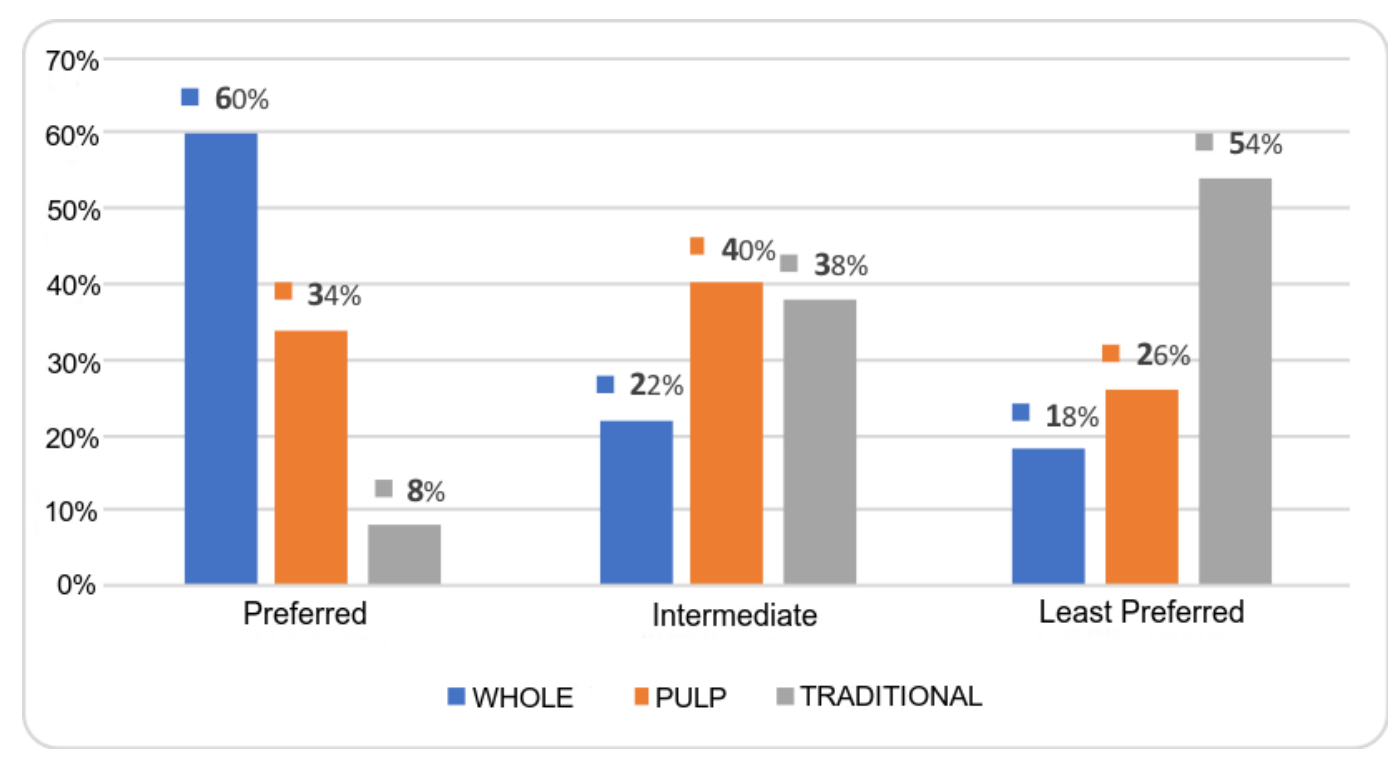

Figure 4. Chocolate Cake Preference Percentage. 
In regards to the purchase intention test (Figure 5), the sample with the highest purchase intention possibility was the green banana biomass with peel, followed by the pulp, and the traditional recipe with the lowest purchase intention. There was no significant statistical difference between the traditional recipe and the other two preparations (Table 5).

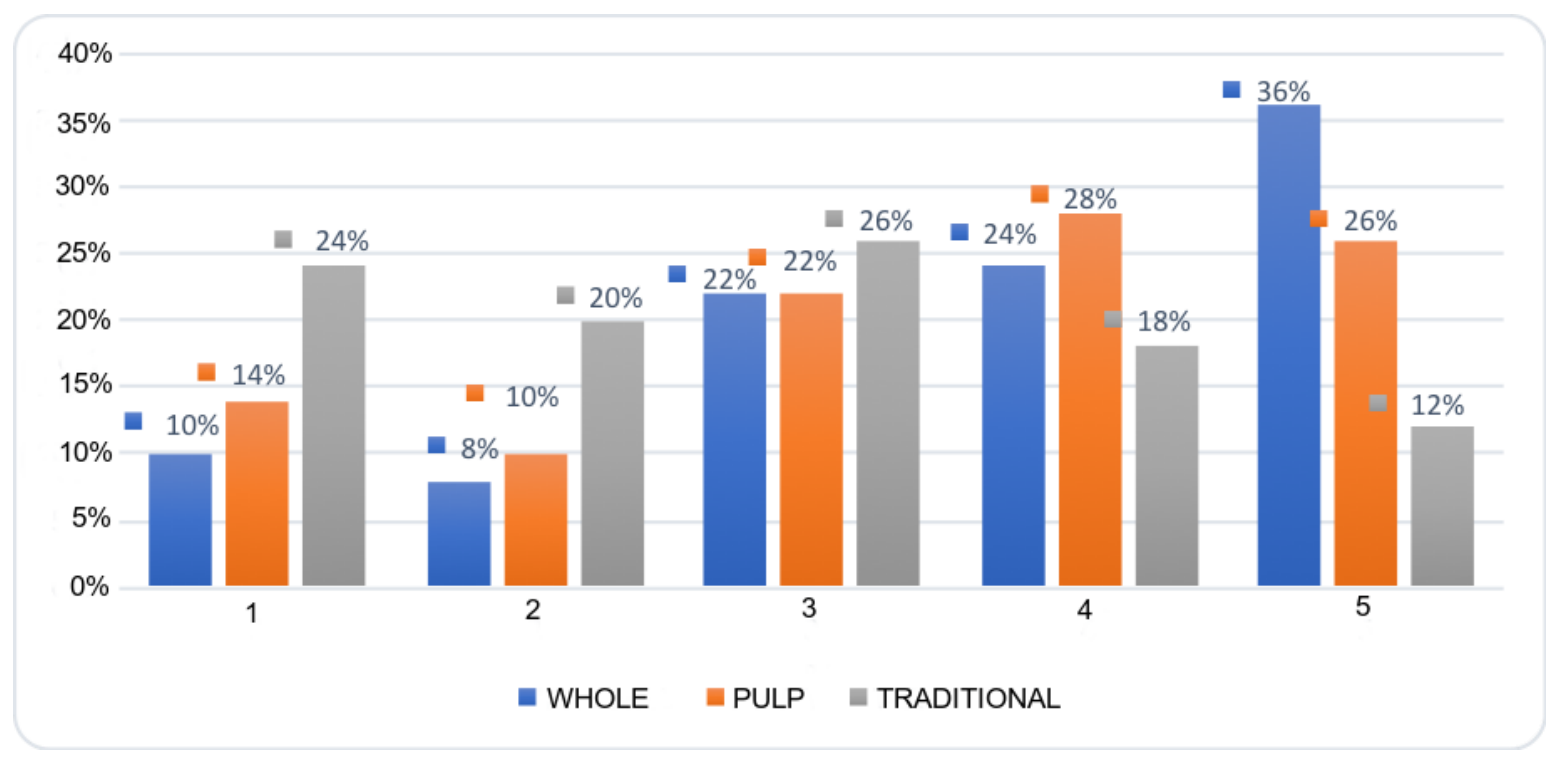

Figure 5. Chocolate Cake purchase intention percentage.

\section{Salty Pie/ Chicken Pie Sensorial Analysis}

Through the analysis of the Cards for the Salty Pie Preference Test Analysis it was possible to characterize participating testers in some aspects. Most testers (84\%) were between 18 and 24 years old, being 76\% female, divided into Unifil students (88\%), with a High School diploma $(90 \%)$ and with the habit ( $70 \%$ ) of consuming food with the intention to prevent diseases.

In the preference test (Figure 6), the traditional recipe showed significant statistical difference in relation to the pulp. The recipe with whole biomass showed no different from the traditional recipe nor from the recipe with green banana pulp biomass (Table 6).

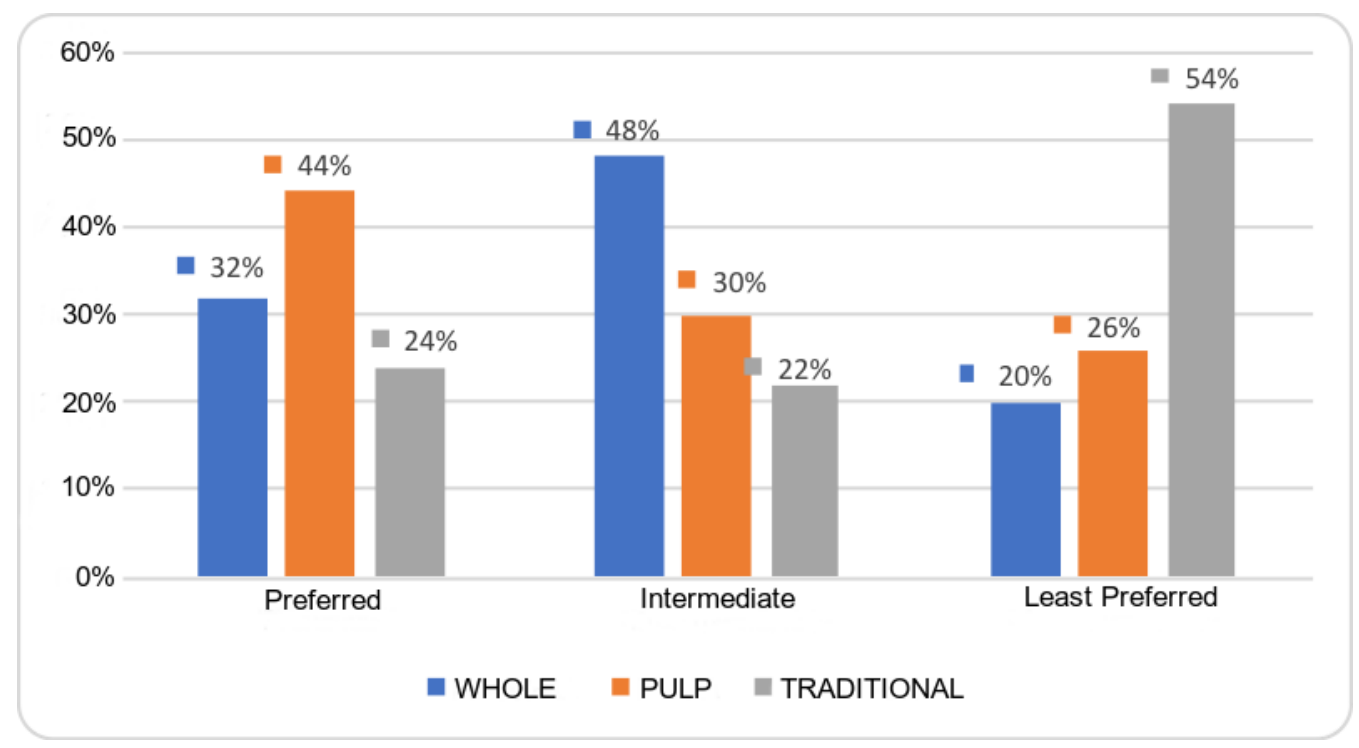

Figure 6. Chicken Pie preference percentage. 
Table 5. Chicken Pie and Chocolate Cake Preference Test.

\begin{tabular}{l|l|l|l}
\hline Means & Whole & Pulp & Traditional \\
\hline Chocolate Cake & $121 \mathrm{a}^{1}$ & $104 \mathrm{a}$ & $77 \mathrm{~b}$ \\
\hline Chicken Pie & $106 \mathrm{ab}$ & $109 \mathrm{a}$ & $85 \mathrm{~b}$ \\
\hline
\end{tabular}

${ }^{1}$ Lower case letters, in the same line, indicate significant difference at $5 \%$, by the Tukey test.

Purchase intention samples were also assessed (Figure 7). Preparations were well accepted. There was no significant statistical difference among preparations (Table 6).

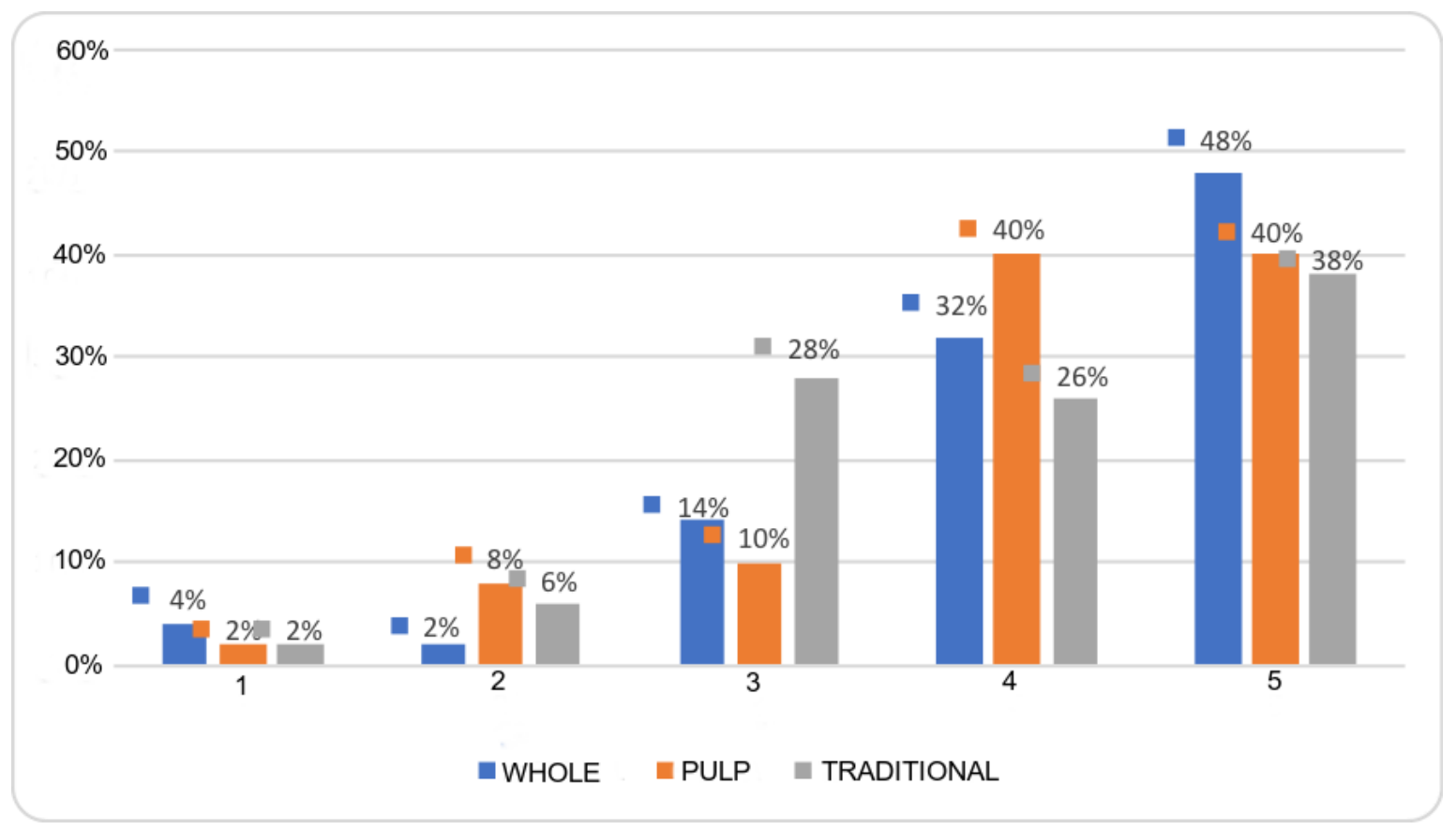

Figure 7. Chicken pie purchase intention percentage.

Table 6. Chicken Pie and Chocolate Cake purchase intention test results.

\begin{tabular}{l|c|c|c}
\hline Means & \multicolumn{1}{|l|}{ Whole } & Pulp & \multicolumn{1}{l}{ Traditional } \\
\hline Chocolate Cake & $3.7 \mathrm{a}^{1} \pm 0.2$ & $3.4 \mathrm{a} \pm 0.2$ & $2.7 \mathrm{~b} \pm 0.2$ \\
\hline Chicken Pie & $4.2 \mathrm{a} \pm 0.1$ & $4.1 \mathrm{a} \pm 0.1$ & $3.9 \mathrm{a} \pm 0.1$ \\
\hline
\end{tabular}

${ }^{1}$ Different lowercase letters, in the same line, indicate significant difference at $5 \%$, by the Tukey Test.

As in the present work, Taipina, Cohen, Mastro, Rodas and Della-Torre (2004) verified that the presence of biomass led to an increase in viscosity and color shade variation during the analysis carried out with mango juice containing green banana pulp biomass compared with the juice without the pulp. Borges, Pereira, Silva-Júnior, Lucena and Sales (2010) observed better quality indexes such as in pre-mix shelf life, texture, softness, appearance and nutritional composition of the cakes as well as cost reduction. There was great acceptance of the recipe in the three studies and no banana odor or taste was detected.

\section{CONCLUSIONS}


There was a preference for chocolate cake recipes containing green banana biomass over the traditional recipe and they presented satisfactory purchase intention. The chicken pie recipe containing pulp biomass showed superior preference over the traditional recipe, and all preparations showed good purchase intention. Therefore, all products developed have great potential to be commercialized with good market acceptance.

\section{REFERENCES}

Anderson, T. J., Jones, R. W., Ai, Y., Houk, R. S., Jane, J. L., Zhao, Y., ... McClelland, J. F. (2014). High-resolution time-of-flight mass spectrometry fingerprinting of metabolites from cecum and distal colon contents of rats fed resistant starch. Analytical and Bioanalytical Chemistry, 406(3), 745-756. https://doi.org/10.1007/s00216-013-7523-8

Aurore, G., Parfait, B., \& Fahrasmane, L. (2009). Bananas, raw materials for making processed food products. Trends in Food Science and Technology, 20(2), 78-91. https://doi.org/10.1016/j.tifs.2008.10.003

Bianchi, M. (2010). Banana Verde-Propriedades e Benefícios. Retrieved from https://docplayer.com.br/6280529-Banana-verde-propriedades-e-beneficios.html

Borges, A. de M., Pereira, J., \& Lucena, E. M. P. (2009). Caracterização da farinha de banana verde. Ciência e Tecnologia de Alimentos, 29(2), 333-339. https://doi.org/10.1590/s0101-20612009000200015

Borges, A. de M., Pereira, J., Silva-Júnior, A., Lucena, E. M. P. de, \& Sales, J. C. (2010). Estabilidade da prémistura de bolo elaborada com $60 \%$ de farinha de banana verde. Ciência e Agrotecnologia, 34(1), 173181. https://doi.org/10.1590/s1413-70542010000100022

Daramola, B., \& Osanyinlusi, S. A. (2006). Production, characterization and application of banana (Musa spp) flour in whole maize. African Journal of Biotechnology, 5(10), 992-995. https://doi.org/10.4314/ajb.v5i10.42830

FAO - Food and Agriculture Organization of the United Nations. (2015). No Title. Rome, Italy: FAO. Retrieved from http://www.fao.org/faostat/en/\#data/QC

Favero, S. M. (w/d). Alimentos funcionais: os prebióticos.

Freitas, J., \& Tavares, Q. (2005). Caracterização do grânulo de amido de bananas. Ciência e Tecnologia de Alimentos, 25(2), 217-222.

Gouveia, P. F., \& Zandonadi, R. P. (2013). Green banana: New alternative for gluten-free products. Agro Food Industry Hi-Tech, 24(3), 49-52.

IAL - Instituto Adolfo Lutz. (2005). Normas analíticas do Instituto Adolfo Lutz. São Paulo, SP.

Kinupp, V. F., \& Lorenzi, H. (2014). Plantas Alimentícias Não Convencionais (PANC) no Brasil: guia de identificação, aspectos nutricionais e receitas ilustradas. Nova Odessa, SP: Instituto Plantarum de estudos da Flora.

Laboratório Bromatológico Nacional. (2002). Exame físico-químico da casca de banana verde cozida e Exame físico-químico da polpa de banana verde cozida. São Paulo, SP.

Lobo, A. R., \& Silva, G. M. L. (2001). Implicações nutricionais no consumo de fibras e amido resistente. Nutrição Em Pauta, 9(49), 28-30.

Medeiros, V. P. Q., Azevedo, S. J. O., Gondim, J. A. M., Gurgel, E. A. S., \& Dantas, A. S. (2005). Determinação da composição centesimal e do teor de minerais da casca e polpa da banana pacovã (Musa paradisíaca I.) produzida no estado do rio grande do norte. Anais Da $57^{a}$ Reunião Anual Da SBPC, 57, w/p. Retrieved from http://www.sbpcnet.org.br/livro/57ra/programas/senior/RESUMOS/resumo_603.html

Nascimento, A. J. S., Pierre, C. F., Santo, N. A. E., Felice, V. A. A., \& Rizzo, J. F. C. (2020). A utilização da biomassa de banana verde na prevenção de doenças. Tekhne e Logos, 11(2), 36-49. 
Pereira, K. D. (2007). Resistant starch, the latest generation of energy control and healthy digestion. Ciencia $e$ Tecnologia de Alimentos, 27(SUPPL.1), 88-92. https://doi.org/10.1590/s0101-20612007000500016

Rabbani, G. H., Larson, C. P., Islam, R., Saha, U. R., \& Kabir, A. (2010). Green banana-supplemented diet in the home management of acute and prolonged diarrhoea in children: A community-based trial in rural Bangladesh. Tropical Medicine and International Health, 15(10), 1132-1139. https://doi.org/10.1111/j.1365-3156.2010.02608.x

Ramos, D. P., Leonel, M., \& Leonel, S. (2009). Amido resistente em farinhas de banana verde. Alimento $e$ Nutrição, 20(3), 479-483.

Rodas, M. A. B., \& Torres, J. C. M. (w/d). Análise sensorial. Retrieved from https://pt.scribd.com/doc/11757612/Analise-Sensorial-de-Alimentos-Capitulo-6

Saad, S. M. I. (2006). Probióticos e prebióticos: o estado da arte. Revista Brasileira de Ciências Farmacêuticas, 42(1), 1-16. https://doi.org/10.1590/s1516-93322006000100002

Saifullah, R., Abbas, F. M. A., Yeoh, S. Y., \& Azhar, M. E. (2009). Utilization of green banana flour as a functional ingredient in yellow noodle. International Food Research Journal, 16(3), 373-379.

Silva, R. E. R., Santos, S. S., Nascimento, T. R. S. M., \& Pimentel, C. V. M. B. (2010). Avaliação do Consumo e Conhecimento sobre Alimentos Funcionais na Estratégia Saúde da Família em uma Unidade Básica de Saúde no bairro de Itaquera. Nutrição Em Pauta, 18(104), 10-14. Retrieved from https://www.nutricaoempauta.com.br/lista_artigo.php?cod=1441

Silva, G. (2003). Banana contra a fome. Partes, 30, w/p. Retrieved from https://revistapartes.com.br/2003/02/14/banana-contra-a-fome/

Silva, A. R. A., \& Araújo, D. G. (2009). SUCO Tropical enriquecido com polpa de banana ( Musa spp .) VERDE. Revista Brasileira DeTecnologia Agroindustrial, 3(2), 47-55.

Taipina, M. S.,Tedeschi, E., Cohen, V. H., Torre, J. C. M. D., Rodas, M. A. B., \& Mastro, N. L. D. (2002). Análise Sensorial de um Suco de Frutas enriquecido com a Biomassa da Banana Verde cozida. São Paulo, SP: IPEN - Instituto de Pesquisas Nucleares. Retrieved from http://www.brazilhost.com.br/bananaverde/ipen.htm

Taipina, M. S., Cohen, V. H., Mastro, N. L., Rodas, M. A. de B., \& Della-Torre, J. C. de M. (2004). Aceitabilidade sensorial de suco de manga adicionado de polpa de banana (Musa sp) verde. Rev. Inst. Adolfo Lutz, 63(1), 49-55.

Valle, H. F., \& Camargos, M. (2010). Yes, nós temos bananas: histórias e receitas com biomassa de banana verde (3rd ed.). SENAC SÃO PAULO.

Received: February 19, 2021.

Accepted: March 20, 2021.

Published: March 31, 2021.

\section{English by: College Language Center}

